ISSN 2088-5415 (Print)

ISSN 2355-5777 (Online)

https://jurnal.ugm.ac.id/kawistara/index

https://doi.org/ 10.22146/kawistara.40397

JURNAL KAWISTARA

VOLUME 9

No. 2, 22 Agustus 2019

Halaman $164-163$

\title{
DE-KULTURALISASI ISLAM DAN KONFLIK SOSIAL DALAM DAKWAH WAHABI DI INDONESIA
}

\section{ISLAM DECULTURALIZATION AND SOCIAL CONFLICT ON WAHHABI MOVEMENT IN INDONESIA}

\author{
*Saipul Hamdi \\ Jurusan Sosiologi Fakultas Ilmu Sosial dan Ilmu Politik \\ Universitas Mataram \\ Submitted:02-11-2018; Revised: 16-04-2016; Accepred: 16-04-2019
}

\begin{abstract}
This article investigates the phenomena of a transnational Wahhabi movement particularly the Wahhabi local organization in Indonesia. Wahhabism is a puritan, textual, and reformist Islamic movement established in Nejd Saudi Arabia 18th century identified as part of the conservative Sunni orthodox tradition. It was determined as the major religious-state reference for shariah law formulation by the Saudi government and expanded to non-Arab countries around the world imposing reformation idea of Islamic religious tradition and academic culture. This article examines the expansion and growth of the Wahhabi local organization in Indonesia and the effort to perform deculturalization of Islam from the local religious tradition practices. Deculturalizing Islam or pulling out Islam from cultural mixture and absorption is not easy because Islam has integrated to the local religious tradition since its presence in the community around the 12th century, which shows a long negotiation and unification of those identities. In doing so, this article explores the response on Wahhabi deculturalization discourse and how the local people negotiate to this new identity and socio-religious transformation influenced by the Wahhabi's teaching and ideology. The hypothesis of Wahhabi's teaching position and role in shaping radicalism and terrorism has carried this research to understand the local context of Wahhabi in Indonesia, how the Wahhabi people understand and engage to radicalism and terrorism, the response to global jihadism propagation including Al-Qaeda and ISIS, and the production of Khilafah Islamiyah idea and mission. The aggressive approach of Wahhabi, which attacks a belief system of local Muslim practices and invigorates the new single identity of Islam, leads this article to investigate the patterns of Wahhabi socio-religious conflict in the communities and the influence to social disintegration existence.
\end{abstract}

Keywords: Deculturalization, Islam; Khilafah Islamiyah; Social Conflict; Wahhabism.

\begin{abstract}
ABSTRAK
Artikel ini menginvestigasi fenomena gerakan transnasional Wahhabi, khsusnya organisasi-organsisasi lokal Wahhabi di Indonesia. Wahhabi merupakan gerakan Islam refromis, puritan, dan tekstual yang didirikan di Nejd, Saudi Arabia pada abad ke-18 yang teridentifikasi sebagai bagian dari kelompok varian Sunni ortodok konservatif. Gerakan ini ditetapkan oleh pemerintah Arab Saudi sebagai rujukan pokok negara-agama dalam merumuskan hukum syariah dan dibantu penyebarannya ke negara-negara luar
\end{abstract}

${ }^{*}$ Corresponding author: shamdi@unram.ac.id.

THE AUTHOR(S).This article is distributed under a Creative Commons Attribution-Share Alike 4.0 International license. Jurnal Kawistara is published by the Graduate School of Universitas Gadjah Mada. 
non-Arab dengan membawa ide reformasi atas tradisi Islam dan kebudayaan akademik. Artikel ini akan menguji ekspansi dan pertumbuhan organisasi lokal Wahhabi di Indonesia dan upayaupaya mereka melakukan dekulturalisasi Islam dari praktik tradisi keagamaan. Dekulturalisasi Islam atau menarik Islam dari pengaruh campuran budaya lokal tidak gampang karena Islam telah terintegrasi dengan tradisi lokal keagamaan sejak kehadirannya di komunitas pada abad ke-12, yang menunjukkan negosiasi dan unifikasi antar identitas tersebut. Oleh karena itu, artikel ini mengeksplor respon masyarakat lokal atas wacana dekulturalisasi oleh Wahhabi, bagaimana masyarakat lokal menegosiasikan identitas baru dan pengaruh transformasi sosialkeagamaan dari ajaran dan ideologi Wahhabi tersebut. Hipotesis tentang posisi dan peran ajaran Wahhabi dalam membentuk radikalisme dan terorisme membawa penelitian ini untuk memahami konteks lokal kelompok-kelompok Wahhabi di Indonesia, bagaimana mereka memahami dan terlibat dalam radikalisme dan terorisme, respon mereka terhadap propaganda jihad global termasuk dari Al-Qaeda dan ISIS, dan produksi ide dan misi penegakan khilafah Islamiyah. Pendekatan Wahhabi yang agresif menyerang sistem kepercayaan dan praktik lokal mendorong identitas tunggal Islam telah mengarahkan artikel ini untuk menginvestigasi pola-pola konflik yang muncul di masyarakat dan pengaruhnya terhadap disintegrasi sosial.

Kata Kunci: Dekulturalisasi; Islam; Khilafah Islamiyah; Konflik Sosial; Wahhabisme.

\section{PENGANTAR}

Wahabisme merupakan salah satu gerakan sosial-keagamaan transnasional yang memiliki pengaruh kuat tidak hanya di kawasan Timur Tengah, tetapi di negara-negara luar seperti Asia, Eropa, dan Amerika. Setelah kerajaan Saudi Arabia mengintegrasikan dan mengonversi ajaran Wahabi sebagai rujukan pokok atas ideologi syariah dan mazhab resmi negara sejak abad ke 19, ajaran Wahabi semakin kuat dan memainkan peran strategis dalam dakwah global Islamiyah. Dukungan ekonomi dan politik dari kerajaan Saudi yang kaya dari hasil minyak bumi hingga mencapai keuntungan $\$ 180$ miliar, yang sebagian dihibahkan untuk dana sosial telah memberikan dampak signifikan atas proses percepatan pengembangan ajaran
Wahabi ke berbagai negara (Algar, 2002; Delong-Bas, 2007; Valentine, 2015). Melalui Islamic Relief dan Qatar foundation dana hibah dialokasikan ke pembangunan masjid, lembaga pendidikan dan majelis taklim di komunitas Wahabi termasuk di Pakistan, Afghanistan, dan Indonesia (Moniquet, 2013:5-8). Meskipun demikian, kehadiran Wahhabisme tidak selalu berdampak positif, tetapi pada aspek tertentu memberi dampak negatif karena secara konstan menentang praktik tradisi keagamaan masyarakat lokal.

Penelitian ini dilakukan selama satu tahun dengan menggunakan metode kualitatif dalam pengambilan dan analisa data. Teknik pengambilan data menggunakan teknik observasi-partisipasi, wawancara, dan diskusi kelompok. Adapun lokasi penelitian di tiga wilayah yaitu ponpes Assunnah, ponpes Jamaluddin dan Ibnu Abbas (Lombok Timur, NTB), ponpes Ibnul Qoyyim (Balikpapan, Kaltim), dan ponpes Bin Baz dan Ihya' AsSunnah (Yogyakarta). Penelitian ini bertujuan untuk memahamai pola-pola de-kulturalisasi Islam yang berkembang di dalam konstruksi kultur keagamaan Wahhabi. Informan yang saya wawancarai berjumlah 30 orang dengan berbagai latar belakang organisasi yaitu tokoh agama dari kalangan Wahhabi, NU, Muhammadiyah, dan Nahdlatul Wathan. Selain itu, saya juga mewawancarai pemerintah daerah, jemaah Wahhabi, dan masyarakat lokal (laki-laki dan perempuan) dengan segmen umur yang juga beragam dari remaja, dewasa, dan lanjut usia.

Wahabismemengklaim sebagai bagian dari Salafi yang Islamnya murni mengikuti secara total sunah Rasulullah dengan berpegangan kepada kitab suci Alquran dan hadis sebagai dalil utama di setiap tindakan mereka. Ulama Wahhabi konsisten mewacanakan pembaharuan keagamaan melalui pemurnian ajaran Islam khususnya pemurnian tauhid menghapus anasir kepercayaan lokal yang dinilai dapat menodai Islam itu sendiri. Seluruh praktik keagamaan yang tidak ditemukan dalam teks dan dipengaruhi atau dicampuri oleh anasir budaya lokal adalah bagian dari bidah, sirik, sesat, dan berpotensi pada kekafiran 
yang harus dijauhkan dari umat Islam (Algar, 2002: 11). Inilah yang menjadi pokok persoalan mengapa Wahabisme seringkali mengalami resistensi dan penolakan kuat dari masyarakat. Artikel ini bertujuan untuk memahami upayaupaya dekulturalisasi Islam (menarik Islam dari budaya lokal) dan negosiasi identitas lokal oleh penganut Wahhabi di tiga wilayah tersebut, dan persoalan-persoalan yang muncul akibat dari dekulturalisasi itu.

Gerakan Wahabisme akhir-akhir ini juga mendapat sorotan keras dari dunia internasional karena ajarannya dinilai kaku dan tekstual menginspirasi prilaku radikal kelompok jihadis. Sebelum peristiwa 9/11, Amerika Serikat adalah sekutu dekat Saudi bekerja sama di bidang permiyakan. Secara politik Amerika juga membantu Saudi dari serangan luar dan ikut membebaskan negara Islam yang disokong oleh Saudi termasuk perlawanan Mujahidin Afghanistan atas Uni Soviet dan koalisinya Democratic Republic of Afghanistan pada tahun 1979-19890 (Commins, 2006: 6). Aksi Osama bin Laden yang disinyalir otak penyerangan gedung WTC dan Pentagon tidak hanya membuat jarak antara Amerika dan Saudi, tetapi mencurigai Saudi sebagai sponsor jihadis dan mempertanyakan peran ajaran Wahhabi sebagai sumber inspirasi atas tindakan terorisme tersebut (Delong-Bas, 2004). Dinamika politik global yang memotret ajaran Wahabi sebagai bagian dari akar terorisme mengarahkan penelitian ini untuk melihat dinamikanya dalam konteks lokal di Indonesia. Pertanyaan adalah sejauh mana pengaruh ajaran Wahabisme membentuk prilaku radikalisme dan terorisme di Indonesia, apakah tokoh-tokoh Wahhabi di Indonesia terlibat di dalam aksi dan jaringan terorisme internasional dan respon mereka terhadap ide pendirian negara Islam.

Ajaran Wahabi yang kaku dan tidak kenal kompromi terhadap sumber di luar Islam telah mengubah perilaku jemaah yang ikut di dalamnya. Mereka meninggalkan identitas lokal dan beralih pada identitas baru yang ke-Wahhabi-an seperti menghindari ziarah makam, menolak tahlilan, menolak peringatan hari kematian yang ditetapkan dalam budaya Jawa, menggunakan jubah, berjenggot panjang, dan lain-lain. Kelompok yang berseberangan dengan Wahhabi akan ditentang, diluruskan dan diisolasi secara wacana, bahkan tidak jarang dakwah Wahhabi berakhir dengan kekerasan sosial. Menarik melihat pola konflik yang muncul antara Wahhabi dengan masyarakat lokal akibat perbedaan dalam pemaknaan kultur Islam. Hampir semua pesantren Wahhabi di awal-awal berdirinya menghadapi tantangan dan konflik sosial yang tajam di masyarakat ketika Wahhabi menentang praktik tradisi yang telah berkembang sebelumnya. Oleh karena itu, artikel ini juga menguji bagaimana dampak kehadiran Wahhabi atas konflik dan disintegrasi sosial di masyarakat dan upaya-upaya meraka dalam mengatasi perpecahan dan konflik tersebut.

\section{PEMBAHASAN \\ De-kulturalisasi islam, Sinkretisme, dan Negosiasi identitas}

Wahhabisme merupakan gerakan lanjutan reformasi Islam jilid satu yang diinisiasi oleh Ibnu Tamiyah pada abad ke 13, digagas kembali pada abad ke 18 oleh Muhammad bin Abdul Wahhab dari Uyainah, Nejd, Arab Saudi (Algar, 2002; Commins, 2006; Delong-Bas, 2007). Meskipun Wahhabi adalah gerakan keagamaan yang membawa wacana pemurnian Islam, tetapi esksistensinya tidak bisa dipisahkan dengan gerakan politik keluarga Saud yang memberontak ke kerajaan Turki Ustmani. Kerja sama antara Wahhab dengan keluarga Saud melahirkan kekuatan poros baru Islam memadukan unsur politik dan agama (Al-Rasheed, 2007: 26; Bonacina, 2015: 30). Wahhabisme diposisikan sebagai fondasi dalam membangun struktur pranata sosial berdasarkan hukum syariah dengan menekankan manhaj salafi, kembali kepada teks asli dan menafikan anasir luar (Al-Rasheed, 2007: 22). Wahhabisme didukung secara politik dan ekonomi sehingga dapat berjalan tanpa gangguan yang signifikan dari aliran lain. Wahhabi adalah kelompok majoritas di Saudi dan sisanya 10\% beraliran Syiah yang tinggal di perbatasan Yaman (Bowen, 2008: 87).

Salah satu agenda pokok gerakan Wahhabi adalah purifikasi wacana ke-Islaman 
dengan pendekatan tafsir yang tekstual dan mempertahankan kemurnian praktik-praktik ibadah mengacu pada fase awal Nabi dan para sahabat yang terekam dalam sunah dan hadis. Apapun yang dikatakan oleh teks (Alquran dan hadis) harus diikuit sebagai kewajiban individu dan menolak segala pengaruh dari sumber luar Islam yang tidak dapat ditemukan dalilnya pada teks agama (Commins, 2009: 11). Bagi Wahhabisme bahwa sumber lain yang tidak ditemukan di dalam teks wajib dibuang meskipun itu positif termasuk dari tradisi lokal. Teks merupakan sumber pokok sebagai rujukan utama untuk melihat apakah praktik itu bagian dari Islam atau bukan. Jika terdapat praktik yang tidak tertulis di dalam Alquran dan hadis maka secara otomatis itu diklaim bidah. Wahhabisme menentang keras praktik bidah karena menciptakan amal baru tanpa petunjuk dari Nabi. Mereka merujuk hadis "Segala yang bari itu bidah dan setiap yang bidah itu sesat, dan kesesatan itu akan berada di neraka" (Chozin, 2013; Commins, 2009; Delong-Bas, 2007).

Saya berargumen bahwa perbedaan pemahaman tentang bidah menjadi pembeda antara Wahhabi dengan kelompok Muslim yang lain. Ormas Islam seperti Nahdlatul Ulama (NU) berbeda pendapat dengan Wahhabi tentang bidah, selama itu berkontribusi positif maka bidah dibolehkan. Sebagai contoh, peringatan maulid Muhammad yang tidak pernah dilakukan oleh Nabi dan sahabatnya dilaksanakan oleh jemaah NU karena dinilai positif pemuliaan kepada Nabi. Bahkan Mahfud MD tokoh NU menyatakan, bidah itu wajib jika untuk kemajuan dan kemaslahatan, Allah saja maha bidah dan maha kreatif. Wahhabi justeru menentang kelompok yang berpegang pada bidah termasuk tokoh agama di luar Wahhabi, bahkan mengkafirkan mereka meskipun hafal Alquran dan alim. Dampaknya konflik dan disintegrasi sosial sulit untuk dihindarkan, apalagi ilmu tasawuf berkembang pesat dan gerakan tarekat menjamur pada waktu itu ikut mendorong kelompok Salafi termasuk Wahhabi melawan gerakan kaum Sufi. Tarekat dinilai tidak berasal dari Nabi karena sesat dan sirik (Hamdi, 2015).
Ide tentang reformasi dan anti bidah menjadi identitas dasar gerakan Wahhabisme di Saudi dan juga di negara lain. Istilah Wahhabisme seringkali disalahpahami dianggap sama persis dengan Salafi, padahal pada titik tertentu ada perbedaan. Salafisme secara umum mempromosikan ajaran Islam yang murni dan memurnikan yang tercapur (Lauziere, 2010; Rubaidi, 2018; Rubin, 2010). Salafisme lebih terbuka dengan politik dan menempatkan politik itu sebagai bagian dari perjuangan, sedangkan Wahhabisme mengharamkan politik dan fokus pada urusan dakwah dan pendidikan Islam (Commins, 2009; Delong-Bas, 2007). Majoritas pengikut Wahhabi terasuk di Indonesia tidak terlibat ke partai politik tertentu. Mereka mendeklarasikan diri sebagai kelompok nonpolitik dan murni bergerak dalam bidang agama. Tentu ini bertolak belakang dengan Wahhabisme di Arab Saudi yang ikut menjadi bagian di dalam pemerintahan, setidaknya menyediakan material dan penguatan sistem lembaga keagamaan mengatur masyarakat.

Sikap yang menentang praktik budaya lokal dan sumber di luar Islam saya sebut dengan istilah de-kulturalisasi Islam, yakni menarik Islam dari akar budaya yang telah menyatu dengan Islam. Diversitas sosial mengenai praktik ritual di dalam komunitas manusia dikenal dengan sinkretisme, mencampurkan berbagai kepercayaan lokal dengan ritual luar termasuk ritual ke-Islaman. Sinkretisme tidak dapat dihindari ketika muncul budaya baru pada ruang budaya lama (Picard dan Madinier, 2011: 2). Kedatangan Islam ke dalam komunitas baru kemungkinan besar akan menghadapi tantangan karena adanya sistem kepercayaan lokal yang eksis jauh sebelumnya. Di sisi lain, ide-ide baru dari Islam yang bersifat kultural tidak semuanya cocok dengan praktik lokal karena Islam lahir dan berkembang pada setting sosial-politik yang berbeda. Nilai budaya Arab memiliki pengaruh besar atas proses penyempurnaan pengetahuan Islam dan berkontribusi pada dasar pembentukannya. Celana cingkrang, jenggot panjang dan burqa adalah sebagian 
dari yang banyak ditentang karena tidak sesuai dengan tradisi lokal (Hefner, 2011: 72).

Bagaimana menegosiasikan dan mengharmoniskan Islam dengan konteks tradisi lokal merupakah bagian dari isu kritis dalam misi reformasi keagamaan Wahhabi. Wahhabi merujuk pada spirit Islam masa Nabi dan sahabat mereformasi penyimpangan ajaran Islam yang dipengaruhi nilai budaya luar yang immoral. Ide reformasi agama ini sensitif untuk dibawa ke tempat dakwah yang baru ketika Islam bukan produk asli dari tradisi lokal. Konsekuensinya, perlawanan terus menguat oleh orang-orang lokal yang merasa terancam. Oleh karena itu, konflik dan kekerasan seringkali terjadi ketika tokoh Wahhabi mensosialisasikan identitas tunggal ke-Islam-an versi Wahhabi yang diklaim paling benar dan yang lain sesat khususnya yang tidak memiliki dasar dalil. Abdulai Iddrissu mengangkat kasus konflik antara kaum Wahhabi dengan Sufi di Afrika yang menyebabkan korban jiwa dari kedua belah pihak (Iddrissu, 2009). Di Indonesia, khususnya di Kaltim, NTB dan Yogyakarta kebanyakan pendakwah Wahhabi menyerang secara frontal, kasar, dan keras terhadap praktik bidah yang berkembang di masyarakat dan memaksakan Islam versi tafsiran mereka.

Dekulturalisasi Islam menyisakan isu besar di dalam komunitas Muslim yang lebih luas di Indonesia, terutama daerah dengan tradisi yang kuat seperti Muslim Sasak di Lombok, Muslim Kutai, dan Dayak di Kaltim serta Muslim Jawa di Yogyakarta. Tidak mudah bagi mereka ikut dalam dakwah Wahhabi karena harus menegosiasikan identitas lokal mereka yang telah tertanam sejak lahir dan diwariskan secara turun temurun. Identitas kebudayaan dan tradisi keagamaan lokal yang melekat dalam diri mereka tiba-tiba harus dibuang dan dihapus dalam identitas keIslam-an yang baru. Setelah bergabung dengan Wahhabi mereka melepas baju adat dan tradisi yang menempel sebelumnya. Selain sikap, tanda yang paling menonjol adalah pakaian digunakan yang dulunya khas Indonesia sekarang khas Arab seperti jubah dan surban. Mereka juga mulai memanjangkan jenggot dan tanda hitam di dahi yang menandakan simbol rajin salat. Majoritas jemaah memiliki tanda hitam di dahi mereka terutama bagi kaum laki-laki, sedangkan kaum perempuan tidak terlihat tanda tersebut. Beberapa pertanyaanpun muncul apakah tanda hitam itu natural atau kultural untuk menunjukkan jati diri orang soleh. Begitu juga dengan model celana yang digunakan harus di atas mata kaki dan di bawah lutut. Celana ini dikenal dengan cela "cingkrang" mengikuti sunah Nabi yang memerintahkan untuk mengangkat sarung ketika berjalan di ruang publik.

Dekulturalisasi Islam juga terlihat dalam perubahan sikap pada tradisi keagamaan masyarakat Muslim yang ada misalnya larangan ziarah ke makam para waliyullah. Daerah Lombok, Yogyakarta, dan Kaltim adalah sebagian dari daerah yang memiliki tradisi ziarah makam yang kuat. Di Lombok misalnya, selain terdapat masjid tua di Bayan, terdapat puluhan situs makam para wali yang dianggap keramat oleh masyarakat lokal. Setiap hari minggu para jemaah dari berbagai desa datang berziarah dan berdoa memintah barokah, keselamatan, jodoh, rezeki, dan kemudahan naik haji (Hefner, 2011: 84). Kegiatan ini sangat ditentang oleh Wahhabi dianggap menyembah makhluk jin yang terdapat di sana. Tidak hanya makam para wali, makam keluarga, dan orang tua juga jarang dikunjungi oleh para jemaah Wahhabi. Tradisi tahlilan setelah meninggal anggota keluarga untuk doa keselamatan juga dilarang. Mereka tidak akan hadir jika diundang tahlilan kematian dengan alasan Nabi tidak pernah melakukan itu. Mereka juga tidak percaya kiriman Alfatihah kepada orang meninggal akan sampai karena itu tidak dianggap doa. Begitu juga dengan peringatan haul berdasarkan ketetapan hari dalam tradisi Jawa juga ditentang karena tidak ada di zaman Rasulullah dan seoalah-olah mengistimewakan hari-hari tertentu, padahal semua hari sama dalam pandangan Wahhabi (Budiman, 2018).

Negosiasi identitas baru di tengah pertarungan identitas lama ini menjadi tantangan tersendiri di dalam diri jemaah Wahhabi. Bahkan identitas tersebut menimbulkan konflik dan perpecahan di masyarakat, dan 
pada saat yang bersamaan jemaah Wahhabi tidak begitu memedulikan hal tersebut karena lebih mementingkan ajaran Islam yang diyakini benar. Pengalaman dari beberapa kasus di lokasi penelitian menunjukkan pertarungan identitas yangtidak mudahbagijemaahWahhabi.Rahmat, santri ponpes Ibnul Qoyyim di Balikpapan dari etnis Kutai menceritakan perasaannya ketika bergabung dengan Wahhabi dan belajar di pondok pesantren ini. Kehidupannya berubah total $100 \%$ dari sebelumnya karena tuntutan sebagai jemaah baru di komunitas Wahhabi. Dia meninggalkan seluruh praktik adat dan tradisi tempat dia lahir, tumbuh, dan berkembang yang dipandang haram di dalam ajaran Wahhabi. Dia meninggalkan keluarga dan orang-orang dekatnya karena mereka masih memegang adat. Di awal-awal bergabung menurutnya cukup memberatkan, tetapi pelan-pelan dia mulai terbiasa setelah beradaptasi dengan dakwah Wahhabi. Bahkan dia lebih tenang, nyaman, dan damai karena tidak terikat dengan adat. Di ponpes ini dia hanya belajar dan beribadah, tidak perlu memikirkan biaya sekolah, makanan, dan tempat tinggal karena semua ditanggung sama pondok (Rahmat, 2018).

Pengalaman Minda, jemaah dari Bagik Nyaka, Lombok Timur menceritakan adanya perubahan besar pada dirinya pasca mengenal ajaran Wahhabi. Dia merasa lebih Islami karena baru mengenal Islam yang sebenarnya. Dia juga mulai meninggalkan praktik-praktik kebudayaan dan adat yang melekat selama ini. Konsekuensinya, dia mengalami isolasi di masyarakat karena prinsip-prinsip yang dipraktikkan tidak sejalan. Orang lokal memandangnya berbeda dari sebelumnya karena tidak lagi menyatu dengan kegiatan di masyarakat. Bahkanadayang melihatnya sebagai musuh karena ikut mengharamkan praktik adat sehingga dia memilih untuk bergaul dengan kelompoknya yang satu ideologi (Minda, 2018). Dian, pengajar di ponpes Bin Baz menyatakan bahwa yang dilakukan adalah printah ajaran Islam yang murni. Apabila kegiatan keagamaan yang terkait ibadah tidak ditemukan dalilnya, maka harus ditinggalkan. Kami tidak akan mengikuti praktik kebudayaan dan adat tersebut lagi karena sia-sia tidak mempunyai pahala, bahkan cenderung menyesatkan. Kita ini berbicara sesuai dalil Islam, bukan membuat dan mewarisi tradisi dari luar Islam (Dian, 2018).

Dekulturalisasi Islam tidak selamanya berjalan dengan baik, tetapi memiliki konsekuensi yang berat. Resistensi dari Muslim lokal sering berakhir dengan konflik dan kekerasan sosial antara Wahhabisme dengan kelompok Muslim yang lain. Saya berargumen bahwa arogansi keagamaan yang mengklaim sebagai kelompok terbaik dan yang lain salah merupakan sumber utama konflik. Ide yang sederhana ini bagi sebagian Muslim telah memunculkan permusuhan terutama di komunitas Muslim yang plural. Hanya karena melindungi ide dan tafsiran keagamaan, mereka mengorbankan ikatan kekeluargaan dan hubungan sosial yang terbangun sebelumnya. Sebagian pengikut Wahhabi tinggal dalam segragasi dari komunitas lokal dan membuat komunitas baru yang ekslusif. Mereka membuat komunitas sendiri dalam kompleks yang besar di dalamnya terdapat sekolah, madrasah, dan lembaga kajian. Komplek ditembok keliling terpisah dengan masyarakat lokal yang tinggal di sekitar mereka.

Suasana yang mirip juga terlihat di lingkungan pondok pesantren Assunah, salah satu Markas Wahhabi yang terbesar di Lombok. Pondok pesantren ini terletak di pinggir jalan utama di desa Bagik Nyaka, Lombok Timur yang di dalamnya sebuah kompleks besar perumahan guru, jemaah, dan santri yang bekerja di sana. Terdapat gedung sekolah, masjid, lembaga kajian, radio, dan lembaga urusan haji dan umrah juga. Pintu kompleks dijaga ketat, setiap tamu harus melapor dan yang boleh tinggal di sana adalah pengikut Wahhabi. Di dalam kompleks ini santri perempuan tinggal terpisah dan mereka tidak boleh berbicara satu sama lain. Ustaz laki-laki menggunakan hijab atau satirah apabila mengajar santri perempuan karena bukan muhrim. Sebagian besar perempuan Wahhabi menggunakan cadar di ruang publik. Ustaz Mizan pimpinan ponpes Assunnah menyatakan, dirinya masih ikut dalam tradisi lokal asalkan tidak menyangkut unsur ibadah. Apabila diundang layatan saya selalu hadir, 
tetapi tidak ikut dalam proses pemakaman dan tahlilan (Mizan, 2018).

Meskipun di dalam prinsip ajaran Wahhabi sangat ketat, tetapi di lapangan saya menemukan ruang-ruang negosiasi antara tradisi dan agama yang lebih fleksibel dan terbuka. Negosiasi ini terlihat ketika jemaah Wahhabi tidak dapat mengikuti ajaran secara penuh karena keadaan lingkungan sosial yang tidak mendukung. Rahmini, Jemaah Wahhabi menceritakan tidak bisa tinggal di dalam rumah terus harus mencari tambahan penghasilan untuk ekonomi keluarganya. Dia tidak menggunakan cadar karena tidak beraktivitas dengan leluasa. Saya cukup memakai kerudung saja karena jika pakai cadar saya tidak bisa bekerja di sawah, katanya. Ketika saya tanya, apakah ibu mengenal istri ustaz di ponpes ini, dia menyatakan kenal nama saja, tetapi jarang berkumpul dan berbicara. Istri beliau juga sangat jarang keluar rumah bergaul dengan masyarakat, katanya. Ungkapan ini menunjukkan bahwa di internal jemaah Wahhabi masih terdapat ruang dialog dan otoritas untuk memilih apakah mampu melaksanakan perintah tersebut atau tidak (Rahmini, 2018).

Di dusun Bantek, Bagik Payung, Lombok Timur, sebuah kampung yang dikenal kuat komunitas Wahhabinya menunjukkan fenomena yang berbeda. Mereka mampu berintegrasi dan beradaptasi dengan masyarakat meskpiun berbeda pandangan keagamaan. Jemaah Wahhabi hidup berdampingan dengan jemaah Nahdlatul Wathan dan Nahdlatul Ulama secara damai dan memiliki hubungan yang cukup baik. Mereka sehari-hari bergaul dengan identitas yang berbeda dan saling menerima perbedaan. Walaupun perempuan Wahhabi menggunakan cadar, tetapi mereka tetap bisa berinteraksi dan berkomunikasi dengan tentangganya. Bahkan mereka ikut hadir di acara-acara adat di masyarakat seperti pesta atau begawe di acara khitanan dan pernikahan. Mereka terlihat biasa dengan cadarnya walapun bergosip dan berbicara di pinggir jalan bersama ibu-ibu yang lain. Peristiwa ini cukup unik karena biasanya perempuan Wahhabi lebih banyak diam di dalam rumah mengurus anak-anak dan melayani suami.

\section{Wahhabisme: Antara Kesetiaan, Radikalisme, dan Khilafah Islamiyah}

Komunitas internasional yang tergabung di Perserikatan Bangsa-Bangsa (PBB) seperti Amerika Serikat, Amerika Latin, dan Eropa memberikan perhatian serius kepada aktivis, ulama, dan jemaah Wahhabi secara umum karena dugaan adanya penyalahgunaan ajaran Wahhabi sebagai sumber ideologi dan doktrin menginspirasi model gerakan yang radikal (Commins, 2009: 124; Jones, 2014). Munculnya kecurigaan ini berdasarkan fakta bahwa para jihadis tidak lagi berperang melawan Uni Soviet, mereka menargetkan serangan ke sekutu (Amerika dan negara-negara NATO) termasuk kantor militer, duta besar, bank, dan aset-aset pemerintah lainnya. Puncaknya adalah peristiwa pembajakan pesawat sipil Amerika yang diledakkan ke gedung World Trade Center dan gedung The Pentagon yang dikenal dengan peristiwa 9/11. Akibat dari peristiwa ini 2.996 orang meninggal dan 6000 orang lainnya mengalami luka-luka. Peristiwa ini merupakan pukulan telak bagi pemerintah dan masyarakat Amerika yang kehilangan keluarga, harta, dan kerusakan infrastruktur yang ditaksir nilainya sekitar \$10 Milliar (Stice, 2005: 24).

Merespon peristiwa tersebut Bush mulai mengkampanyekan perang global terhadap terorisme. Bush menyasar sekolah-sekolah Muslimuntuksterilisasipengaruhajaranradikal termasuk di Indonesia (Hamdi, Carnegie, dan Smith, 2015). Perang dimulai dari Afghanistan dengan menargetkan Taliban yang dikenal rezim konservatif. Taliban berkuasa sejak 1996-2001 setelah memenangkan perang sipil dengan pemerintah Negara Islam Afghanistan yang dipimpin oleh presiden Ahammad Shah Massoud (Rogers, 2004: 5). Perang sipil 19921996 antara faksi-faksi Islam di Afghanistan terjadi sejak mereka berhasil mengusir Uni Soviet (1978-1992) dari Afghanistan. Pemerintah Taliban menerapkan hukum syariah secara ketat yang berdampak pada diskriminasi kaum perempuan. Kemiskinan 
dan kekacauan akibat perang saudara tidak mampu diatasi oleh Taliban, bahkan keadaan semakin memburuk. PBB yang mulai investigasi menemukan berbagai ketimpangan sosial di Afghanistan. PBB mengalami kendala ketika bantuan kemanusiaan dihalang-halangi masuk oleh Omar karena tidak begitu senang dengan kehadiran aktivis NGO dan negaranegara Barat. Kantor NGO banyak ditutup paksa oleh Omar dan juga kantor perwakilan PBB di Kandahar (Feifer, 2009: 9).

Osama bin Laden adalah tokoh penting di balik kesuksesan Taliban menuju singgasana kekuasaan. Selain dibantu oleh Muhammad Ziaul Haq, Taliban juga dibantu oleh Al-Qaeda, organisasi jihadis yang didirikan oleh Osama bin Laden pada 1998. Al-Qaeda memiliki sayap di berbagai negara dan bercita-cita mendirikan khilafah Islamiyah dalam konteks global. Latar belakang bin Laden teknokrat keturunan Saudi Arabia menjadi dasar kuat melihat pengaruh Wahhabisme di dalam gerakan jihad dan teror (Romero, 2007). Bin Laden dituduh sebagai inisiator pembajakan pesawat dan serangan ke WTC di Amerika. Meskipun melahirkan kontrovesi di dunia Islam dan membuka pandangan baru tentang peran ajaran Wahhabi dalam membentuk prilaku jihad, ajaran Wahhabi menjadi bahan kajian oleh akademisi. Kesimpulan yang muncul bahwa pendiri AlQaeda yang beraliran Wahhabi Sunni Islam menunjukkan adanya korelasi antara Wahhabi dengan gerakan terorisme pasca kasus 9/11 (Romero, 2007; Moore dan Tumetly, 2009).

Bagaimana menguji korelasi ajaran Wahhabisme dengan radikalisme. Sulit untuk membuktikan kebenaran asumsi tersebut melihat ajaran asli yang ditulis oleh pendiri Wahhabi tidak ada yang spesifik mengajarkan kekerasan. Delong-Bas (2004: 193-194) menyatakan bahwa tidak ada tulisan Wahhab yang memerintahkan jihad secara sporadis dan melegalkan pembantaian secara brutal. Jihad memiliki mekanisme yang ketat dalam ajaran Wahhabi termasuk larangan membunuh anakanak dan kaum perempuan. Apakah mungkin karena faktor kebetulan dalam pristiwa perang di Afghanistan, yang mana banyak jihadis dari kalangan Wahhabi datang berperang karena dorongan fatwa. Syaikh Bin Baz mengeluarkan fatwa jihad di Afghanistan sebagai kewajiban individu (fardu ain). Fatwa ini memiliki dampak besar tidak hanya pada Jemaah Wahhabi, tetapi komunitas Muslim dari seluruh dunia juga ambil bagian dalam misi "jihad khsus" melawan otoritas komunis (Jones, 2014). Abu Bakar Ba'asyir, Saleh Sungkar, Ja'far Umar Thalib dan tokoh-tokoh dari berbagi negara terlibat perang di Afghanistan. Mereka dilatih oleh Central Intelegent Agency (CIA) melawan Uni Soviet. Ini merupakan tahap awal fase pelibatan jihad komunal, khususnya mereka yang mengklaim sebagai Islam faksi Salafi dan Wahhabi (Hamid, 2016: 7).

Tidak semua alumni jihadis perang Afghanistan mengambil jalan sebagai teroris bergabung dengan Al-Qaeda besutan Osama bin Laden. Ustaz Ja'far Umar Thalib misalnya menyatakan, dirinya tidak setuju dengan aksi kekerasan dan terorisme Al-Qaeda karena itu tidak diajarkan di dalam ajaran Wahhabi. Bahkan beliau menyatakan Osama bin Laden adalah tokoh yang kurang paham ajaran Islam. Menurutnya pasca perang suci dengan Uni Soviet maka tugas jihad telah selesai. Akan tetapi, faktanya banyak dari jemaah Wahhabi yang telah teracuni oleh kelompok Ikhwanul Muslimin dari Mesir yang juga ikut berjihad pada waktu itu. Mereka inilah yang mencuci otak jemaah Wahhabi dan berbalik melawan negara-negara Barat karena ingin mendirikan negara Islam. Tahlib berusaha menjauhi dan fokus belajar pada salah satu gurunya di Yaman. Setelah pulang ke Indonesia beliau tidak termasuk bagian dari Jamaah Islamiyah, dia mendirikan kelompok Laskar Jihad yang ikut berperang membela Muslimin di Ambon. Setelah Laskar Jihad dibubarkan beliau konsen menyebarkan Islam di Papua dan mengurus ponpes Ihya' As-Sunah di Jl. Kaliurang, Degolan, Yogyakarta (Hasan, 2007:85).

Penulis berargumen bahwa prinsip ajaran Wahhabi tidak mendukung secara spesifik ide tentang jihad. Ini adalah murni gerakan reformasi keagamaan yang mempromosikan pendekatan baru mengenai tauhid dan dakwah Islam mengikuti jejak kehidupan awal Nabi dan sahabatnya. Menurut ajaran Wahhabi, Islam 
pada generasi awal merupakan yang terbaik murni tanpa inovasi-inovasi baru. Semua datang melalui Nabi Muhammad berdasarkan wahyu Allah bukan hawa nafsu. Inovasi atau bidah berkembang pesat sejak generasi ketiga Islam, sebagian sarjana mengembangkan ide dan pengetahuan tentang topik spiritual yang lebih dikenal dengan praktik tasawuf (Delong-Bas, 2004: 42). Oleh karenanya, asumsi yang berkembang menimbulkan pertanyaan bagaimana Wahhabi menjadi kelompok radikal dan terlibat di dalam gerakan radikalisme. Mayoritas sarjana internasional seperti Ahmad Algar (2002), Ahmad Fauzi Abdul Hamid (2016) dan Giovanni Bonacina (2015) berhipotesis, ajaran Wahabi telah menginspirasi prilaku radikal dan teror terhadap komunitas agama lain. Sebagai peneliti saya melihat, hipotesis ini membutuhkan eksplorasi yang lebih jauh karena hasilnya berbeda di lapangan misalnya di Lombok, Balikpapan, dan Yogyakarta yang menunjukkan bahwa komunitas Wahhabi tidak terlibat di dalam aksi terorisme. Akan tetapi, penulis ingin menekankan bahwa terdapat "potensi" ajaran Wahhabisme yang dapat dieksploitasi sebagai legitimasi kekerasan.

Perang Afghanistan dan fatwa ulama Wahhabi untuk berjihad secara personal tidak hanya menginspirasi kelompok Salafi menjadi jihadis temporer, tetapi juga legitimasi untuk penyebaran ideologi terorisme ke seluruh dunia (Taskarina, 2018: 29). Sebagian alumni termasuk Ba'asyir contohnya, menyebarkan, dan mengajarkan ideologi jihad dan teror melalui pengajian, majelis taklim, dan memilih berseberangan dengan pemerintah. Ba'asyir, mantan aktivis Gerakan Pemuda Islam Indonesia, Ketua Lembaga Dakwah Mahasiswa Islam, dan pendiri ponpes Ngruki telah ditunjuk sebagai Amir Jamaah Islamiyah (JI), sayap AlQaeda di Asia Tenggara. Dia diduga salah satu aktor intelektual dari berbagai kasus bom yang terjadi termasuk di Bali, Jakarta, Kalimantan, Sulawesi, Yogyakarta, Solo dan Bima (Hamid, 2016: 8). Sebagian martir yang tertangkap adalah santri Ba'asyir dari alumni ponpes Al-Mukmin Ngeruki Sukoharjo. Meskipun tuduhan ini dibantah oleh Ba'asyir, tetapi pemerintah menemukan bukti atas keterlibatannya dalam kasus pelatihan kelompok teroris di Aceh dan beliau langsung dipenjarakan di Nusa Kambangan (Abdullah, 2018: 220).

SetelahpemerintahIndonesiamenjatuhkan hukuman terhadap Ba'asyir selama 15 tahun di penjara, ini kemudian tidak menghentikan langkah perjuangannya mengembangkan ajaran jihad. Meskipun diam di penjara, tetapi ideologinya terus tersebar di kalangan Muslim garis keras. Santrinya aktif melanjutkan ajaran jihad Ba'asyir konsolidasi membangun kekuatan melalui lembaga pendidikan dan majelis taklim. Banyak pesantren baru yang didirikan khusus untuk menggembleng para martir dan syuhada siap mati sebagai pengantin demi tegaknya agama. Setidaknya terdapat 16 pondok pesantren yang terindikasi mengajar konsep jihad dan terorisme, 41 masjid penceramah memaparkan ideologi jihad, dan hate speech. Pondok pesantren Ibn Mas'ud Bogor salah satu pesantren yang baru yang terindikasi menyiapkan kader-kader jihadis berperang ke Syuriah. Temuan ini dikuatkan dengan meninggalnya Hatf Saiful Rasul bocah berumur 11 tahun di perang Suriah, santri dari ponpes Ibnu Mas'ud. Oleh karena itu, saya berargumen bahwa ide-ide Ba'asyir tentang jihad seakan tidak pernah mati, dan sebaliknya bermetamorfosis dalam beragam bentuk organisasi dan Ormas. Jemaah Ansharut Daulah (JAD) dan Mujahidin Indonesia Timur (MIT) adalah dua di antara sekian banyak sel gerakan terorisme di Indonesia. Mereka tidak lagi bergerak dan menggunakan simbol konservatisme Islam, mereka lebih terbuka dan adaptif dengan media (Abdullah, 2018: 215).

Perubahan peta politik terorisme global juga berpengaruh pada peta lokal jihadis di Indonesia. Kehadiran Islamic State of Iraq and Syiria (ISIS) berhasil menggantikan posisi AlQaeda pasca penangkapan dan pembunuhan Osama Bin Laden oleh tentara elit Amerika di Pakistan. ISIS sukses mengembangkan jaringan barunya ke seluruh dunia termasuk di Indonesia (Moore dan Tumetly, 2009). Gerakan propaganda ISIS lebih massif dari Al-Qaeda karena menggunakan media cetak dan elektronik. Anak-anak muda terobsesi dengan aksi heorik ISIS yang dipandang cool. 
Munculnya isitlah "jihad cool" di kalangan anak muda Eropa tidak lepas dari pendekatan ISIS melalui media online. ISIS mendapat simpati yang cukup signifikan di Indonesia terbukti dengan sumpah setia kepada pemimpin ISIS di Syuriah termasuk JAD dan MIT. Keduanya menggunakan pendekatan yang lebih lebih terbuka melawan pemerintah dengan jihad di ruang publik. Dalam kasus bom Tamrin Januari 2016 mereka mengubah identitias teroris yang sebelumnya memakai jubah, surban, dan jenggot panjang, ke pakaian yang biasa (Abdullah, 2018: 219; (Taskarina, 2018).

Kasus-kasus radikalisme dan terorisme tersebut menyisakan satu pertanyaan besar terkait peran pengikut Wahhabisme dalam skenario ini. Sulit untuk mengidentifikasi langsung keterlibatan Wahhabisme karena identitas Wahhabi tidak tunggal, tetapi plural. Aliran Wahhabi di Indonesia berdiri sendiri tanpa ada pusat komando dari pusat Timur Tengah. Mereka menerima bantuan amal (charity) dari beberapa lembaga funding Timur Tengah, namun mereka diberi kebebasan untuk mendesain lembaga pendidikan sendiri asalkan ajaran Wahhabiyahnya tidak dihilangkan. Istilah Wahhabi dan Salafi seringkali bertukar posisi digunakan secara bergantian dengan maksud yang sama, sedangkan keduanya memiliki perbedaan pada aspek tertentu. Dari hasil wawancara di lapangan menunjukkan bahwa mayoritas pengikut Wahhabi tidak setuju dengan istilah Wahhabi, mereka lebih suka dipanggil salafi karena hubungannya dengan manhaj, metode atau cara dalam bertauhid. Menurut Rahman (2018) tokoh Wahabi dari Bagik Nyaka Lombok Timur, tidak benar orang memanggil kami dengan sebutan Wahhabi karena ini tidak ada hubungan dengan Abdul Wahhab, ini adalah kebenaran Islam. Hanya sebagian kecil yang setuju termasuk ustaz Thalib yang menerangkan jika dirinya tidak keberatan dengan sebutan istilah Wahhabi.

Temuan saya di lapangan menunjukkan bahwa pondok pesantren Wahhabi yang menjadi tempat lokasi penelitian saya yaitu ponpes Assunah, Jamaludin Al-Manar dan Ibnu Abbas Lombok Timur, Ibnul Qoyyim Balikpapan, dan Bin Baz dan Ihya' As-Sunah
Yograkata tidak terkait dengan jaringan terorisme dan radikalisme. Tidak pernah ada kasus santri mereka terlibat pada aksiaksi pengboman dan teror. Yayasan Assunah di Lombok contohnya lebih fokus pada pengembangan pendidikan formal dan informal berbasis komunitas mendirikan lembaga pendidikan dari TK sampai perguruan tinggi Ma'had Ali. Tidak ada ajaran kebencian atau seruan jihad fisik kepada kelompok non-Muislim. Hidayat, salah satu guru di Yayasan Assunah menjelaskan tentang komitmen kesetiaannya kepada pemerintah Indonesia dan menentang upaya radikalisasi dan demonstrasi. Dia menyatakan, meskipun bukan negara syariah yang menerapkan hukum Islam secara formal dan kafah, tetapi secara informal dan sosial pada dasarnya adalah negara syariah karena memiliki kebebasan untuk mempraktikkan ajaran Islam. Kami tidak menyentuh wilayah politik dalam misi kami dan tidak pernah juga mendukung ide-ide khilafah Islamiyah. Secara total mengikuti dan mendukung semua kebijakan pemerintah, bahkan mereka memiliki hak untuk mengambil harta kami dengan jalan ilegal (Hidayat, 2018).

Hidayat juga menjelaskan sikap ponpes yang tidak ikut dalam aksi 212 pada tahun 2016 di Jakarta ketika kasus Al-Maidah ayat 51. Dia menambahkan haram demonstrasi bagi jemaah Wahhabi di komunitasnya. Setiap tanggal 17 Agustus kami ikut merayakan hari kemerdekaan bangsa Indonesia dengan mengibarkan bendera di ponpes kami. Sebagai peneliti saya kaget dengan adanya pemasangan bendera merah putih di ponpes Wahhabi karena selama ini mereka diasumsikan sebagai ponpes yang konservatif dan tidak berjiwa nasionalis. Posisi yang sama juga disampaikan ustaz Ali, pengurus ponpes Jamaluddin menyatakan, jemaah Wahhabi memiliki hubungan baik dengan pemerintah dan tidak akan pernah melawan pemerintahan yang sah. Ponpes Jamaluddin tidak pernah mendukung demontrasi dan kami tetap konsisten berjuang di jalur pendidikan dan dakwah. Ustaz Abdul Gafur dari ponpes Ibnu Abbas juga menyampaikan komitmen jemaah Wahhabi yang tidak pernah aneh-aneh membuat masalah dengan pemerintah. Kami sangat loyal kepada pemerintah yang 
sah karena merekalah pemimpin kami yang melindungi kami. Kami tidak mengajarkan tentang jihad, kami fokus pada tahfizul Quran, dan mengajarkan bahasa Arab.

Pengurus ponpes Ibnul Qoyyim Balikpapan Kaltim membuka pintu mereka ke publik dan aparat keamanan untuk melihat langsung dan menilai apakah mereka bagian dari kelompok terorisme atau tidak. Beberapa ustaz (Fahirah, Irsyan dan Jauhari, 2018) yang saya wawancarai menyatakan," pintu ponpes terbuka kepada siapapun yang ingin mengetahui kegiatan pendidikan dan keagamaan kami serta dapat langsung mengikuti ceramah agama oleh para ustaz. Kami capek dituduh teroris ketika muncul kasus pengeboman di Indonesia, padahal kami tidak terlibar sama sekali". Data yang sama juga saya temukan di ponpes Bin Baz yang menunjukkan arah perjuangan Wahhabisme terfokus pada pendidikan dan dakwah. Rafi'i, salah satu ustaz di ponpes Bin Baz menyatakan bahwa kurikulum ponpes ini tidak mengajarkan radikalisme dan terorisme, yang diajarkan adalah Islam yang sebenarnya, Islam yang berdasarkan pada dalil-dalil agama dari Alquran dan hadis. Selain pendidikan formal, ponpes kami ini juga memiliki program sosial, ekonomi, dan kesehatan seperti rumah sakit dan ruko yang besar untuk memenuhi kebutuhan warga dan para santri. Jangan salah paham dengan ponpes kami, katanya (Rafi'i, 2018).

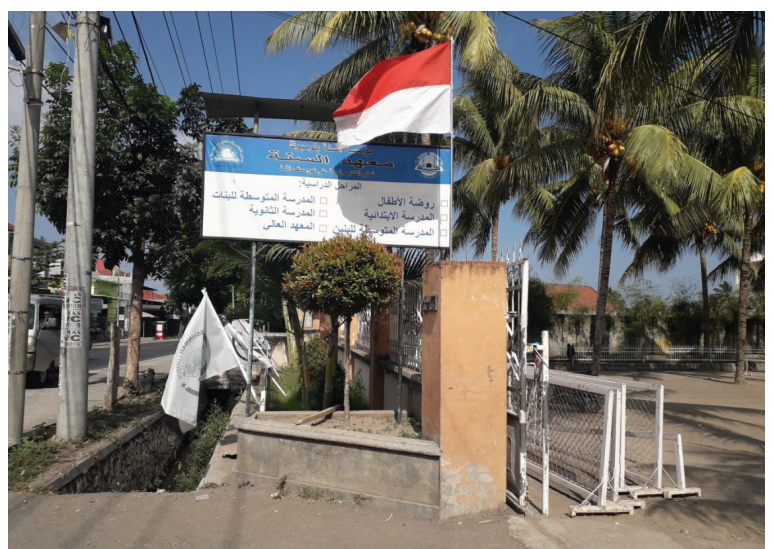

Gambar 1

Bendera Merah Putih di Gapura ponpes Assunnah, Bagik Nyaka, Lombok Timur, NTB dalam Rangka Memperingati Hari Kemerdekaan 17 Agustus 2018.

Sumber: Dokumen Pribadi Penulis (2018)

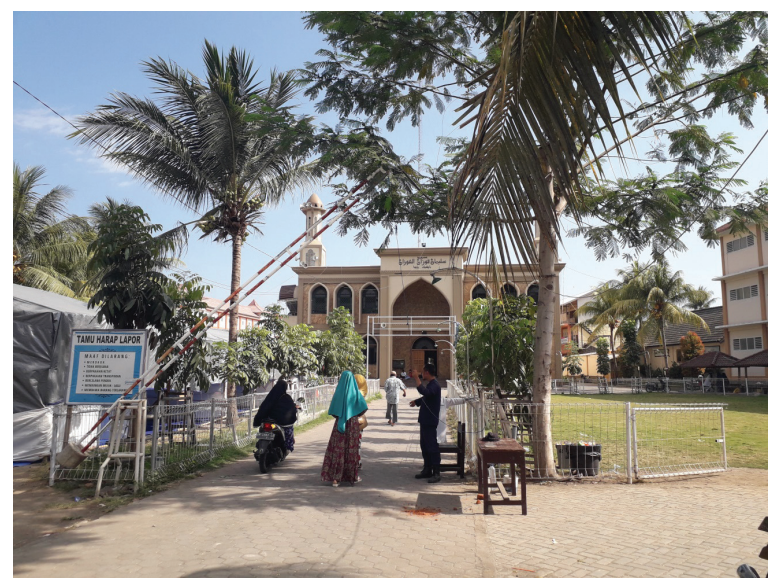

Gambar 2

Lokasi Bangunan Ponpes Assunah di Bagik Nyaka Lombok Timur, NTB.

Sumber: Dokumen Pribadi Penulis, (2018)

\section{Reproduksi Konflik Sosial dalam Dakwah Wahhabisme}

Gerakan Wahhabisme juga dikenal dengan muwahhidin, yaitu gerakan pemurnian tauhid mengajak umat Islam untuk meninggalkan praktik-praktik yang berpotensi pada kesirikan. Gerakan pemurnian versi Wahhabi sangat kaku dan eksklusif, tidak mau menerima kebenaran dari sumber-sumber di luar Islam termasuk sumber dari kebudayaan dan kearifan lokal. Mereka hanya berpegang pada teks kitab suci Islam, yaitu Alquran dan hadis. Kitab suci seoalah-olah dijadikan "Tuhan", tidak bisa tergantikan dengan sumber lain meskipun memberikan konstribusi positif. Ide-ide permunian ini dijadikan prinsip dalam dakwah Wahhabi yang wajib disampaikan kepada masyarakat Muslim. Wahhabi tidak memandang kearifan lokal yang berkembang di masyarakat, jika berlawanan dengan nilai ke-Islam-an harus dilawan, didakwahi, dan diarahkan kembali ke Islam yang benar. Pendekatan ulama dan aktivis Wahhabi cenderung keras, kasar, dan tidak peka dengan perasaan masyarakat, bahkan siap untuk konfrontasi selama itu dianggap tidak sesuai dengan Islam. Sikap inilah yang seringkali menimbulkan konflik dan perpecahan di masyarakat (Abdullah, 2018; Hamdi, Carnegie dan Smith, 2015; Hasan, 2007). 
Bagian ini mengeksplorasi tentang fenomena konflik sosial-keagamaan akibat pendekatan dakwah kelompok Wahhabi di ketiga daerah tersebut. Konflik sosialkeagamaan merupakan tantangan serius yang dihadapi oleh pengikuti Wahhabi dan masyarakat lokal karena pemaksaan ide purifikasi secara masif di setiap langkah dakwahnya, yang seringkali kontras dan berseberangan dengan praktik-praktik tradisi keagamaan lokal. Karena mayoritas jemaah Wahhabi di Indonesia terutama di Lombok, Balikpapan dan Yogyakarta percaya bahwa misi mereka adalah misi Islam dan penafsiran mereka adalah yang paling benar karena semua itu harus disampaikan melalui dakwah yang berkelanjutan di manapun dan kapanpun jemaah Wahhabi berada tanpa mempertimbangkan dan melihat latar sosial masyarakat lokal. Dalam konteks tertentu, kasus ini menunjukkan bahwa pendakwah Wahhabi kurang peduli dan peka terhadap respon dan perlawanan kelompok Muslim lokal. Saya berargumen bahwa perilaku keagamaan tokoh dan aktivis Wahhabi inilah yang telah mendorong dan menciptakan konflik dan perpecahan sosial.

Data lapangan menunjukkan bahwa konflik sosial yang melibatkan kelompok Wahhabi tidak hanya terjadi di tingkat eksternal antara Wahhabi dengan masyarakat lokal, tetapi juga di internal Wahhabi sendiri karena perbedaan sikap dan kepentingan dari tokoh-tokoh tersebut. Akan tetapi konflik internal ini tidak sampai menimbulkan perang fisik antara pimpinan Wahhabi. Tuan Guru Haji (TGH) Husni, salah satu pelopor Wahhabisme di Lombok Timur mengalami perpecahan dengan saudaranya Tuan Guru Abdul Manar karena perbedaan pandangan tentang politik. Husni tidak setuju dengan keterlibatan Manar di politik dan memintanya untuk fokus ke dakwah. Abdul Manar aktif di partai Golkar dan terpilih sebagai anggota DPRD pada masa Suharto. Dikarenakan tidak mendengar saran dari kakaknya membuat mereka terpecah. Husni pindah dari ponpes Jamaluddin kemudian mendirikan markas baru yang sekarang dikenal dengan ponpes Assunah.
Tokoh Wahhabi di Yogyakarta juga terpecah menjadi dua kelompok, yaitu kelompok Ustaz Ja'far Umar Thalib dan kelompok Yusuf Utsman Ba'itsaa. Thalib bersama santrinya mendirikan Forum Komunikasi Ahlussunah wal Jamaah (FKAWJ) dan Laskar Jihad, sedangkan Ba'itsa dan ulama Wahhabi yang lain seperti Abu Nida' Chamsaha Sofwan, Ainur Rafiq Ghufran, Yazid bin Abdul Qadir Jawaz, dan Ahamd Faiz Asifuddin menolak bergabung di Laskar Jihad dan keluar dari forum FKAWJ. Mereka mendirikan pondok masing-masing dan salah satunya adalah ponpes Bin Baz yang berada di daerah Bantul.

Konflik eksternal pertama kali menimpa kelompok Wahhabisme dapat dilacak dalam peristiwa konflik yang terjadi di Sumatera. Kedatangan Wahhabi ke pulau Nusantara mulai berlangsung sejak awal abad ke 19 yang dibawa oleh para ulama modern Islam dari Sumatera Barat yang berlajar di Mekkah. Ketika kembali ke Sumatera mereka tergabung dalam kelompok "Kaum Padri" menyebarkan ajaran Wahhabisme kepada masyarakat lokal. Komunitas Padri menghadapi perlawanan keras dari kelompok adat setelah membatasi peran adat di medan agama (Abdullah, 2018; Hasan, 2007). Konflik antara Wahhabi dengan masyarakat lokal juga terlihat di berbagai daerah di Indonesia. Di desa Peringga Sela Lombok Timur, masyarakat lokal menentang keinginan jemaah Wahhabi untuk membangun masjid terpisah dengan masjid masyarakat. Alasan penolakan ini karena selain ajaran Wahhabi bertolak belakang dengan tradisi masyarakat Muslim Sasak, tetapi juga telah menggangu stabilitas keamanan masyarakat karena sikap keras kelompok Wahhabi yang menentang praktik lokal. Ahmad, salah satu warga menjelaskan, masyarakat lokal tidak menolak dakwah Wahhabi, tetapi mereka menyerang dan menuduh kami sebagai kelompok sesat, musrik dan ahli bidah karena kami memiliki tradisi dan praktik lokal yang masih dipertahankan. Tokoh-tokoh Wahhabi melalui pengeras suara di masjid menyalahkan rusaknya Islam di desa tersebut dan menantang kaum intelektual untuk berdebat secara terbuka mencari siapa yang paling benar. 
Ketika tokoh-tokoh Wahhabi dari Peringga Sela mulai membangun masjid sendiri terpisah dari komunitas, orang lokal menyerang mereka dengan melempar batu ke pengikut Wahhabi dan berusaha merusak masjid yang baru berdiri fondasinya. Sementara jemaah Wahhabi bertahan untuk melindungi masjid mereka dari pelemparan batu. Kekerasan ini berlangsung selama tiga kali dan akhirnya pemerintah lokal memfasilitasi mereka. Kedua kubu setuju untuk rekonsiliasi dan mengakhiri konflik. Pengikut Wahhabi melanjutkan pembangunan masjid, tetapi dengan catatan tidak boleh menyinggung kelompok lain dalam dakwahnya. Konflik yang sama juga terjadi di Sakra dan Lombok Tengah di mana masjid Wahhabi dibakar dan jemaahnya diusir dari kampung. Mereka tidak boleh berdakwah di masyarakat karena dinilai merusak tatanan masyarakat lokal yang arif, damai dan tenang (Ahmad, 2018). Di tahun 2000 di desa Suralaga Lombok Timur, atap masjid tempat pengajian Wahhabi dilempar dengan batu oleh orang tidak kenal dan pengajianpun harus dihentikan. Di Kampug lain Dusun Baru, Suralaga, Pimpinan Wahhabi ustaz Wardi dan jemaahnya diserang menggunakan parang oleh masyarakat lokal berupaya merusak mushala yang dipakai pengajian. Ustaz Wardi dikenal keras menantang berdebat secara terbuka kyai-kyai lokal melalui pengeras suara di pengajiannya.

Jemaah Wahhabi di pesantren Ibnul Qoyyim Balikpapan juga mengalami pengalaman yang sama menghadapai konflik dengan masyarakat lokal di sekitar pesantren. Kehadiran mereka telah menggangu kenyamanan masyarakat karena menyerang praktik ajaran lokal yang telah lama berjalan. Pemerintah daerah menfasilitasi debat terbuka antara tokoh Wahhabi dengan NU untuk mencari sisi persamaan dan perbedaan sehingga memeperoleh titik temu. Debat tidak berjalan dengan lancar karena tokoh perwakilan Wahhabi tidak mau melanjutkan acara di sesi debat. Dia minta izin pulang terlebih dahulu karena ada keperluan keluarga. Saifuddin (2018), seorang kyai dari Samarinda menceritakan serangan keras ustaz Wahhabi yang mendebatnya ketika mengisi pengajian di jemaahnya. Dari kasus ini, saya menyimpulkan bahwa wacana dan pendekatan di dalam dakwah Wahhabi sangat agresif dan mencoba untuk memaksa orang lain mengikuti tafsir keagamaan mereka. Sikap arogansi ini menjadi isu utama yang perlu dicarikan solusi supaya ajaran Wahhabi lebih terbuka melihat praktik lokal yang berkembang di masyarakat. Terlebih misalnya Wahhabi tidak dapat menghindari konflik ini karena meyakini misi agama harus didakwahkan. Dakwah ini dianggap sebagai tugas suci agama Islam yang pernah diperjuangkan oleh Rasulullah dan harus dilanjutkan (Abdullah, 2018; Commins, 2009: 125; Hasan, 2007: 87).

\section{SIMPULAN}

Jemaah Wahhabi termasuk kelompok minoritas di Indonesia dalam hal pengikut, tetapi kekuatan dan komitmen mereka dalam pengembangan di bidang dakwah dan pendidikan keagamaan patut diapresiasi. Lembaga pendidikan di bawah underbow Wahhabi terus berkembang pesat dan mampu bersaing dengan madrasah dari Ormas lain. Masalah klasik hanya pendekatan keras dan agresif di dalam menjalankan misi dakwah ke masyarakat lokal yang biasanya menyebabkan respon negatif dan perlawanan balik ke tokohtokoh Wahhabi oleh masyarakat lokal itu sendiri. Pola dan pendekatan dakwah yang hard approach dan frontal menyerang simbolsimbol adat dan budaya lokal merupakan salah satu sumber utama konflik dan perpecahan. Upaya dekulturalisasi Islam Wahhabi ini membutuhkan evaluasi yang mendalam dan menyeluruh meskipun misi utama Wahhabi dalam purifikasi Islam tidak semua ditolak oleh masyarakat lokal.

Kehadiran Wahhabisme tidak selalu berdampak positif bagi pembangunan SDM masyarakat, tetapi juga berdampak negatif di beberapa aspek dalam kehidupan masyarakat, yang mana setiap jemaah yang mau bergabung dituntut untuk mengubah dan meninggalkan identitas kebudayaan ke-Islam-an yang lama. Selain konflik batin pada diri jemaah, konflik sosial juga seringkali muncul akibat dekulturalisasi Islam yang dilakukan secara 
masif dan konsisten oleh Wahhabi. Adanya asumsi tentang peran ajaran Wahhabi yang dapat mempengaruhi dan membentuk prilaku radikalisme dan terorisme tidak semuanya benar jika melihat hasil temuan saya di lapangan. Hampir di semua pesantren Wahhabi yang saya kunjungi tidak memiliki kurikulum yang spesifik tentang jihad di dalam institusi pendidikan mereka. Sebaliknya, saya menemukan data baru tentang komitmen tokohtokoh Wahhabi untuk menjaga persatuan, kesatuan bangsa, taat kepada pemerintah yang sah dan melawan gerakan radikalisme. Mereka juga tidak memiliki agenda pendirian negara Islam atau khilafah Islamiyah di Indonesia, dan sebagian berpandangan bahwa Indonesia pada dasarnya adalah negara syariah karena memiliki kebebasan menjalankan ibadah tanpa didikte oleh pemerintah.

\section{DAFTAR PUSTAKA}

Abdullah, Asaman. 2018. Radikalisasi Gerakan Jamaah Ansharut Tauhid dan Pengaruh ISIS Di Indonesia. Sosiologi Reflektif, 12(2):213-232

Algar, Hamid. 2002. Wahhabism: A Critical Essay, New York: IPI

Al-Rasheed, Madawi. 2007. Contesting the Saudi State: Islamic Voices from a New Generation. Cambridge : Cambridge University

Bonacina, Giovanni. 2015. The Wahhabis Seen through European Eyes (1772-1830): Deists and Puritans of Islam. Leiden: Brill

Bowen, Wayne H. 2008. The History of Saudi Arabia. London: Greenwood Press.

Chozin, Muhammad Ali. 2013. Strategi Dakwah Salafi di Indonesia. Journal Dakwah, 16(1):1-25.

Commins, David. 2009. The Wahhabi Mission and Saudi Arabia. London dan New York: I.B. Tauris.

Delong-Bas, Natana J. 2007. Wahhabi Islam: From Revival and Reform to Global Jihad. London: I.B. Tauris.
Feifer, Gregory, 2009. The Great Gamble: The Soviet War in Afghanistan. E-book: Harper Collins

Hamdi, Saipul 2015. Demazhabization of Islam, Divinity Economy and Narrative of Conflict on the Tablighi Followers in Samarinda East Kalimantan, Al Albab Bourneo Journal of Religious Studies, 4(2):146-168.

Hamdi, Saipul, Smith, Bianca J, dan Carnegie, Paul J. 2015. The Recovery of a Non-Violent Identity for an Islamist Pesantren in an Age of Terror,' Australian Journal of International Affair, 69(6):1-19.

Hamid, Ahmad Fauzi Abdul. 2016. ISIS in Southeast Asia: Internalized Wahhabism is a Major Factor, Perspective, 24(1):1-11.

Hasan, Noorhaidi. 2007. TheSalafi Movement in Indonesia: Transnational Dynamics and Local Development, Comparative Studies of South Asia, Africa and the Middle East, 27(1):8394.

Hefner, Robert W. 2011. "Where have all the abangan gone? Religionization and the decline of non-standard Islam in contemporary Indonesia", dalam Picard, Michel dan Madinier, Rémy, The Politics of Religion in Indonesia Syncretism, Orthodox, and Religious Contention in Java And Bali. London dan New York: Routledge.

Iddrissu, Abdulai. 2009. Contesting Islam: Homegrown Wahhabisme, Education and Muslim Identity in Northern Ghana 1920-2005. Disertasi di Department of History, University of Illinois At Urbana Campaign.

Jones, Seth G. 2014. A Persistent Threat the Evolution of Al-Qa'ida and other Salafi Jihadist. Washinton: Rand Corporation.

Lauziere, Henri. 2010. The Construction of Salafiyya: Reconsidering Salafism from The Perspective of Conceptual 
History. International Journal of Middle East Studi, 42(3):369-389.

Moore, Cerwyn Dan Tumetly Paul. 2009. Assesing Unholy Alliances in Chechnya from Communism and Nationalism to Islamism and Salafism, Journal of Communist Studies and Transnational Politics. 25(1):74-94.

Moniquet, Claude. 2013. The Involvement of Salafism/Wahhabism in the Support and Supply of Arms to Rebel Groups Around the World. A report by Ceo, European Strategic Intelligence And Security Center (Esisc), Belgium.

Picard, Michel dan Madinier, Rémy. 2011. The Politics of Religion in Indonesia Syncretism, Orthodox, and Religious Contention in Java and Bali. London dan New York: Routledge.

Rogers, Paul. 2004. A waron Terror: Afghanistan and After. London: Pluto Press.

Romero, Antonio J. 2007. The Different Faces of Islamic Terrorism. Journal of International Review of Sociology, 17(3):444-458.

Rubaidi, A. 2008. Radikalisme, Nahdlatul Ulama \& Masa depan Moderatisme di Indonesia. Bandung: Logung Pustaka.

Rubin, Barry M. 2010. Guide to Islamist Movements. New York: M.E Sharpe

Stice, Ralph W. 2005. The Convergence of Current Events, Biblical Prophecy and the Vision of Islam: From 9/11 to 666. Nasvhille: Acw Press.

Taskarina, Leebarty. 2018. Perempuan dan Terorisme: Kisah Perempuan dalam Kejahatan Terorisme. Jakarta: Gramedia.

Valentine, Simon Ross. 2015. Force and Fanaticism: Wahhabism in Saudi Arabia and Beyond. London: Oxford University Press.

\section{Sumber Wawancara:}

Ahmad. (2018, September). Wawancara Personal Budiman. (2018, 04 Maret). Wawancara Personal Dian. (2018, Februari). Wawancara Personal Fahirah, Irsyan, dan Jauhari. (2018, Februari). Wawancara Personal

Hidayat. (2018, Agustus). Wawancara Personal Minda. (2018 Mei). Wawancara Personal Mizan. (2018, Juli). Wawancara Personal Rahmat. (2018, Maret). Wawancara Personal Rahmini. (2018, Agustus). Wawancara Personal Rahman. (2018, Agustus). Wawancara Personal Rafi'i. (2018, Mei). Wawancara Personal Saifuddin. (2018, April). Wawancara Personal 